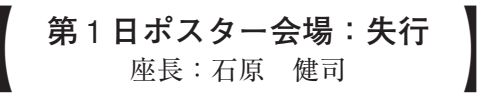

\section{I-P2-1観念運動失行に対するジェスチャー訓練と感覚情 報变換訓練における治療効果の比較}

寺田萌 ${ }^{1}$, 河野正志 ${ }^{1}$, 清水大輔 ${ }^{2}$, 富永孝紀 ${ }^{1}$

${ }^{1}$ 医療法人穂翔会村田病院リハビリテーション部, ${ }^{2}$ 大阪保 健医療大学

〔はじめに〕観念運動失行（IMA）に対する治療法として， ジェスチャー訓練 (Smania 2006) や失行症を脳内の感覚情報 変換におけるマッチングの機能不全に由来するとした感覚情 報変換訓練 (Perfetti 1996) が報告されている。今回, 運動の 産出（production）で構成されたジェスチャー訓練と, 運動 の産出と解読 (decording) で構成された情報変換訓練を比較 し, IMA 患者における運動麻痺と IMA に対する治療効果を 検討したので報告する。

〔症例〕本研究に同意を得た 70 歳代の右利き男性。左 MCA 領域の広範な梗塞を認め, 発症 5 か月後の BRS は上肢 5 , 手指 3 , 感覚は中等度 重度鈍麻で, IMA, 全失語を呈 した。KOHS は IQ90 でSPTA では錯行為や保続, 拙劣さを 認めたが, ジェスチャーの認知や行為の概念は保たれていた。

〔方法〕シングルケースデザインを用い， $\mathrm{AA}^{\prime}$ を情報変換 訓練期, $\mathrm{BB}^{\prime}$ をジェスチャー訓練期とし, 各期は週 2 回の頻 度で 7 回とした。情報変換訓練は視覚や体性感覚を解読さ せ, 視覚と視覚や視覚と体性感覚をマッチングさせる訓練を 麻痺側手中心に実施した。ジェスチャー訓練は Smania らの 手続きに準じ非麻痺側手を用いて実施した。治療効果は, 運 動麻痺を Wolf motor function test (WMFT), IMA を SPTA の 運動麻瘦の影響を除いた誤反応得点を用いて比較検討した。

〔結果〕WMFTは介入前, $\mathrm{ABA}^{\prime} \mathrm{B}^{\prime}$ の順に 1083，631，646, 563，534 秒，SPTAは $62 ， 43 ， 33 ， 44 ， 21$ 点であった。

〔考察〕運動麻疩は, ジェスチャー訓練に比べ情報変換訓 練で改善した。これは, 情報変換訓練が麻疩側手に直接介入 したことが要因だと考えられた。一方, 失行症状は, 情報変 換訓練に比べジェスチャー訓練で改善した。これは, ジェス チャー訓練では非麻瘏側手を用いたため, 上り多様な運動イ メージを想起させ，それらを元にした実運動が可能であった ことが要因だと考えられた。今後は, 訓練における麻疩側, 非麻痺側手の使用を考虑して検討を重ねていきたい。

\section{I-P2-3 右利き，右優位の失行を呈した大脳皮質基底核症 候群の一例}

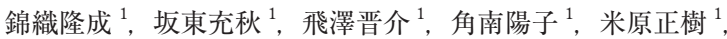
木田耕太 ${ }^{1}$, 阪口優理 ${ }^{2}$, 磯崎英治 ${ }^{1}$

${ }^{1}$ 東京都立神経病院脳神経内科, ${ }^{2}$ 東京都立神経病院精神科

〔症例〕 75 歳, 女性, 右利き。

〔現病歴〕 $\mathrm{X}-5$ 年に歩きづらさ, $\mathrm{X}-4$ 年に右上肢の動かしづ らさを自覚し, 徐々に悪化した。 $X-1$ 年 4 月から靴を履く際 に右下肢が勝手に動くようになった。同年 9 月から家事をす る際に右上肢が勝手に動くようになった。X年 1 月に精査した。

〔神経学的所見〕右上下肢に軽度の痓性, 腱反射充進, 病
的反射を認めた。指鼻試験と膝踵試験は, 失行があり右側は 評価できず，左側は測定障害と運動分解を認めた。四肢の温 痛覚は正常で, 四肢の振動覚は軽度低下, 位置覚は両足趾で 正常であった。右足のぶん回し歩行が見られた。

〔高次機能所見】口頭指示 $>$ 模倣 $>$ 物品の順に強い右優位 の上下肢の失行があり, 右優位の肢節運動失行もあった。拮 抗失行, 口顔面失行, 失語, 失認, 失書, 構成障害, visuomotor ataxia はなかった。

〔心理所見] MMSE-J 29，FAB 13。RCPM 31。RAVLT 直 後再生, 遅延再生とも問題なし。KWCSTは試行 IでCA 2 で PEN 11 だが，施行 II でCA 5 PEN 5 と改善した。

【画像所見】頭部単純 MRI：両側前頭頭頂葉の萎縮あり, 2014 年から 2016 年にかけて進行を認めた。中心溝付近の大 脳萎縮の程度は左側で強い。左大脳脚と中脳被蓋の萎縮を認 めた。123I-IMP-SPECTで左頭頂葉外側, 左前頭葉の血流低 下を認めたが，2014 年から 2016 年にかけて変化は見られな かった。

〔考察〕 Possible CBS / clinical criteria for possible CBD (Armstrong's criteria) 以上の基準を満たし, 大脳皮質基底核症候群 と診断した。右優位の失行は報告が少ない。脳梁病変が明ら かでなく, 左中心領を中心とした病変が疑われるので左半球 内離断症状の可能性もあるが, 変性疾患であることから行為の 優位性が右半球にある交叉性失行の可能性がより考えやすい。

\section{I-P2-4 大脳皮質基底核症候群（CBS）の着衣障害に対 する指導方法の検討}

大西慶彦 ${ }^{1}$, 田中尚 ${ }^{2}$, 難波忠明 ${ }^{3}$, 岸本大 ${ }^{1}$, 猪野正志 ${ }^{4}$, 小 澤恭子 $^{5}$

${ }^{1}$ 洛和会音羽病院リハビリテーション部, ${ }^{2}$ 音羽病院リハビ リテーション科, ${ }^{3}$ 音羽リハビリテーション病院リハビリテー ション部, ${ }^{4}$ 音羽病院高次脳機能障害センター, ${ }^{5}$ 音羽病院 神経内科

〔はじめに〕大脳皮質基底核症候群 (CBS) の着衣障害と介 助方法を検討したので報告する。

〔対象〕臨床的に CBS と診断された外来通院中の右利き女 性 3 例（60 歳代 2 名, 70 歳代 1 例）。全例, 一側性優位の肢 節運動失行 (LKA) (左 2 例, 右 1 例), 皮質性感覚障害, 筋 固縮, 構音障害を認めた。軽度の空間無視, 構成障害を認め た。発症経過は $1 \sim 3$ 年で, MMSE 26 ～30/30, FAB 10 16/18, BI 80 〜 100 であった。

〔結果〕全例，上肢挙上などの粗大な運動は可能であり， ボタンを留める程度の巧緻機能は保たれていたが, 着衣動作 は拙劣で時間がかかり着衣障害と考えた。特に, LKAがあ る患側上肢から袖を通すと袖に引っかかり時間がかかるだけ でなく, 左右や裏表の間違いもあり, 着衣障害が顕著であっ た。巧繳障害に加えて, 無視や構成障害の影響も考えられ た。さらに患側上肢から着ると着方がわからなくなると訴え た。他人に服を着せることは全例可能であった。一方，LKA がない健側上肢から袖を通すと着衣は比較的容易であり， ADL 指導を行った。ところが， 1 例においては, 約 1 年の経 過で，筋固縮が進行し，筋関節可動域 $(\mathrm{ROM})$ 制限が強くな ると，患側から袖を通した方が動作が容易であった。 
〔考察〕CBSでは，LKAのある患側上肢から袖を通すと着 衣障害が顕著で, これにはLKAに加えて, 無視, 構成障害, さらには着衣失行, 脳梁失行といった要因が関与していると 推察された。通常, 脳卒中患者では, 麻痺のある患側から着 衣を指導するが, 今回のCBS例では, 患側上肢からの着衣は 困難であった。一方，健側からの着衣指導を行ったところ有 効であった。しかし症状が進行し ROM 制限が重度となった 1 例では, 患側上肢からの着衣が比較的容易となった。CBS では症状の進行度合いに応じて適切な着衣方法の選択が必要 であると考えられた。CBSの着衣障害の病態や指導につい ては, 左右差, 病期も含めたさらなる検討が必要である。

\section{I-P2-5 ウェルニッケ失語と行為の障害がみられた患者が 排泄動作の獲得に至った経過}

岩井静華 ${ }^{1}$, 原寛美 ${ }^{1}$

${ }^{1}$ 医療法人社団敬仁会桔梗ヶ原病院

〔はじめに〕失行とは学習された意図的行為を遂行する能 力の障害であり, 中枢神経系の損傷によって生じる。失行と呼 ぶには失語による理解障害が行為の障害の直接の原因であっ てはならないとされている。しかし, 今回, 失語による理解 障害だけでは説明し難い行為の障害がみられた症例を経験 し，排泄動作獲得にまで至ったので経過を報告する。

〔症例〕 80 代女性。右利き。既往に左後頭葉・頭頂葉皮質 下出血があるが家族からの情報によると目立った症状はみら れず, 排泄は自立していた。今回, 左後頭葉・頭頂葉・側頭 葉皮質下出血を再発。リハ目的で 47 病日目に当院へ転院。 重度のウェルニッケ失語, 全般性注意障害, 右半側空間無 視, 右身体失認に加え行為の障害を認めた。行為の障害とは 具体的に排泄後, 下衣を上げてから陰部を清拭するなどの系 列動作の誤り，トイレットペーパーを上手くちぎれなかった り, 洗浄レバーを回せなかったりと道具の使用の困難さ, 便 器の中を流れる水で手を洗おうとするなどの概念の障害を認 めた。更に右半側空間無視により右側にある障害物にぶつか り，転倒リスクも高かったため排泄動作を含めた ADL は全 般的に介助が必要であった。神経心理検査は失語による理解 障害により MMSEは復唱のみ加点の 3 点, SLTAも単語の復 唱が 3 割正当したのみであった。Kohs は練習問題も困難で あり，失行のスクリーニングテストも困難であったが, 状況 理解は比較的良好であった。作業療法では errorless learning を促すため作業療法士がまず一連の排泄動作を見せ，模倣さ せるという練習を繰り返し行った。途中経過ではできる時と できない時があったが 173 病日目には一連の排泄動作が可能 となった。これらは同じ動作でもできる時とできない時があ る, 口頭命令よりも模倣が容易, 検査場面よりも日常生活場 面の方が容易などの失行の一般的特徵と一致していると考え られる。また, 模倣と反復が動作獲得に有効であると思われた。

\section{I-P2-6 失行症状のみの時期が先行しその後急速に進行し た大脳皮質基底核症候群の 1 例}

中田る ${ }^{1}$, 中尾洋子 ${ }^{1}$, 佐藤秀代 ${ }^{1}$, 瀬戸牧子 ${ }^{1}$, 佐藤聡 ${ }^{1}$,

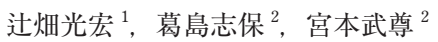

${ }^{1}$ 長崎北病院神経内科, ${ }^{2}$ 長崎北病院リハビリテーション部 〔目的〕大脳皮質基底核症候群（corticobasal syndrome）は 進行性の左右非対称の筋強剛と失行を特徴とする疾患である が, 診断項目にある症状の出現時期については診断基準では 言及していない。初期に失行症状のみを呈した CBS の症例 を報告する。

〔方法〕症例は 75 歳男性。 $\mathrm{X}$ 年 1 月よりネクタイが結べな い, ボタンがかけられない, 靴紐を結べないなどの症状が出現 した。X 年 6 月に当院へ入院した際には認知機能低下や運動 症状を認めなかったが, 更衣や道具の使用に支障があった。 指の運動は拙劣で, 狐や敬礼, 手を振るなどのジェスチャー は不可, 釘を打つ, 歯磨きのパントマイム不可であり, 肢節 運動失行, 観念運動失行を認めた。はさみは使用できず, 図 形の模写は不良で簡単な菱形も書けなかった。腱反射立進, Babinski 徵候陽性, MMSE 27 点, FAB 12 点であった。初診 時, 失行症状に明らかな左右差はなく, 脳萎縮や頭頂葉の血 流低下に左右差を認めなかった。入院中の 3 ケ月の間に固縮 と構音障害が進行し, 把握反射などの前頭葉徵候, 他人の手 徵候を認めるようになった。発症 14 ケ月の MRI VSRAD では 白質ボリュームの左右差を認め, 左優位に頭頂葉の萎縮を認 めた。また脳血流検査でも左右差が出現し左側優位に低下し た。MMSEは 25 点, FAB 7 点であった。発症 16 ケ月で歩行 不能となり車椅子となった。発症 24 ケ月で, 手足の指示動 作は全くできず，両手は握った状態から開かず， MMSE 10 点, FAB 0 点でコミュニケーションをとるのが困難となった。

〔結果〕初診時には失行が主症状で認知機能低下やパー キンソニズムは目立たなかったものの, 徐々に症状, 脳萎 縮, 脳血流の左右差が顕在化し, 臨床的にCBS と診断した。

〔考察〕初発症状である失行症状のみの時期が半年ほどあ りその後急速に進行した症例であったが, CBS はその病変 分布によって多彩な臨床像を呈する疾患であり, その 1 例と して考察を加えて報告する。

\section{I-P2-7 脳梗塞後の失行症状に対して電化製品の使用を目} 指した 1 症例

藤原彰二 ${ }^{1}$, 永田英利 ${ }^{1}$, 永尾友美 ${ }^{1}$, 羽山史織 ${ }^{1}$, 出永文也 ${ }^{1}$, 岩永勝 ${ }^{1}$

1 特定医療法人東筑会東筑病院リハビリテーション科

〔症例〕 73 歳右利き女性。

〔現病歴〕本人寝室より声が聞こえ, 倒れているところを 家族が発見し, 近医へ救急搬送される。

〔画像所見〕頭部 CT 上に左側頭葉〜頭頂葉に低吸収域あり。

〔神経学的所見〕運動麻痺なし。

〔神経心理学的所見〕全般性注意障害, 構成障害, 記憶障 害 (ベントン視覚記銘力検査 : $5 / 10$ ), 失行症 (ガスコンロの 使用 : 行為の順番の間違いと省略 洗濯機 : 行為の順番の間 違い 電子レンジ：形を成さない無意味な運動 炊飯器：道 具や対象との関係の間違い), 失語症 (SLTA：聴覚的理解が 短文レベル, 表出面では呼称 2 割程度, 非言語的コミュニケー ション良好)。

〔経過〕発症直後は, 重度の失語症と日常生活レベルでの 観念失行・観念運動失行症状見られたが, 入院生活を行って いく上での物品使用は可能となり, 自宅復帰をめざし X+ 
$4 \mathrm{~W}$ より当院入院となった。 $\mathrm{X}+4 \sim 8 \mathrm{~W}$ では, 病院内で全般 的な注意機能訓練を中心に実施し, $\mathrm{X}+8 \mathrm{~W}$ より自宅での動 作確認を行った際, ガスコンロ・洗濯機・炊飯器・電子レン ジの使用が困難であった。そのため, 家事動作自立を目指し た電化製品の手順の指導をエラーレス訓練法で 4 度に分けて 実施した。

〔結果〕ガスコンロは, 手順の間違いがなくなり, スムー ズに着火までの工程が行えるようになった。洗濯機も手順の 間違いがなくなった。炊飯器は, 適切な手順で道具の使用が 可能となった。電子レンジは, 出力・時間を合わせる工程で 混乱見られ，作業獲得には至らなかった。

[考察]先行研究より, 失行症状に対して机上訓練よりも 現実に即した実際の訓練が有効であると報告されている。今 回の症例は, 電子レンジの使用に関しては不十分であったも のの, 全体として先行研究を支持する結果となった。電子レ ンジの使用の動作学習が進まなかった要因として, 作業の工 程が複雑であり自由度が高いこと, 訓練頻度が少なかったこ と, 病前の使用頻度が少なかったことが考えられた。 